\title{
Penerapan Metode Pembelajaran Tutor Sebaya pada Program FTIK IAIN Pontianak Mengaji
}

\author{
Budiyono \\ Institut Agama Islam Negeri (IAIN) Pontianak, Kalimantan Barat, Indonesia \\ Email: budi2014.yono@gmail.com
}

\begin{tabular}{l}
\hline Tersedia Online di \\
\hline http://www.jurnal.unublitar.ac.id/ \\
index.php/briliant \\
\hline \\
\hline Sejarah Artikel \\
\hline Diterima pada 1 Juli 2020 \\
Disetujui pada 25 Agustus 2020 \\
Dipublikasikan pada 31 Agustus \\
2020 Hal. 499-510 \\
\hline \\
\hline Kata Kunci: \\
\hline FTIK Mengaji; Membaca Al- \\
Qur'an; Tutor Sebaya \\
\hline \\
\hline DOI: \\
\hline http://dx.doi.org/10.28926/briliant \\
.v3i4.495
\end{tabular}

\begin{abstract}
Abstrak: FTIK Mengaji adalah program peningkatan kemampuan membaca al-qur'an mahasiswa menggunakan metode tutor sebaya. Peneliti melakukan pengamatan sebagai masukan untuk menentukan langkah-langkah selanjutnya. Adapun temuan penelitian; (1) Jenis Program: Tahsin al-Qur'an, pembinaan akhlakul karimah, praktik ibadah. (2) Perencanaan program: Pengawasan melalui absensi, menentukan kriteria tutor, fokus meningkatkan kemampuan makharijul huruf dan Tajwid. (3) Pelaksanaan program: Wajib mematuhi tata tertib program, Klasifikasi kemampuan terdiri dari tinggi, sedang, rendah, menggunakan metode bimbingan satu per satu dihadapan tutor, tutor berasal dari mahasiswa dengan kategori kemampuan tinggi, program terlaksana dengan baik dan hambatannya beberapa mahasiswa tidak hadir tepat waktu.
\end{abstract}

\section{PENDAHULUAN}

Profil lulusan Fakultas Tarbiyah dan Ilmu Keguruan (FTIK) IAIN Pontianak salah satunya memiliki kemampuan menguasai pengetahuan bidang kajian keislaman. Hal tersebut menjadi ciri khusus yang menjadi pembeda antara lulusan program studi bidang ilmu keguruan di Institut Agama Islam Negeri (IAIN) dengan Perguruan Tinggi lain pada bidang keilmuan sejenis. Fakultas Tarbiyah dan Ilmu Keguruan (FTIK) IAIN Pontianak memiliki 4 (empat) Program Studi antara lain Pendidikan Agama Islam (PAI), Pendidikan Bahasa Arab (PBA), Pendidikan Guru Madrasah Ibtidaiyah (PGMI) dan Pendidikan Islam Anak Usia Dini (PIAUD). Kemudian, terdapat 2 (dua) Program Studi baru yakni Tadris Bahasa Inggris dan Tadris Matematika yang mulai menerima pendaftaran mahasiswa pada tahun akademik 2020/2021.

Mahasiswa di FTIK IAIN Pontianak tidak hanya dibekali dengan kompetensi Keguruan tetapi dituntut untuk menguasai kajian keislaman, maka penyelanggara pendidikan di fakultas tersebut bertanggung jawab untuk memastikan seluruh mahasiswa memiliki kompetensi tentang konsep keislaman yang baik, salah satunya indikatornya yakni menguasai teknik membaca al-Qur'an. Berdasarkan pendapat Manna Khalil al-Qattan salah satu syarat menjadi mufassir (orang yang menafsirkan) al-qur'an yakni memiliki kemampuan membaca alQur'an, kemampuan menafsirkan al-qur'an diperlukan karena al-qur'an menjadi landasan kajian keislaman (Imam Masrur, 2018:195). 
Berdasarkan pengamatan selama berlangsungnya proses pembelajaran di FTIK IAIN Pontianak masih banyak ditemukan mahasiwa yang belum memiliki kemampuan membaca al-qur'an dengan baik. Latar belakang pendidikan disinyalir menjadi salah satu penyebabnya, mahasiswa dengan latar belakang pendidikan di Pondok Pesantren dan Madrasah berbasis Islam memiliki kemampuan membaca alqur'an relatif lebih baik dibanding mahasiswa dengan latar belakang pendidikan dari Sekolah umum (SD/SMP/SMA/SMK). Meskipun tidak sedikit mahasiswa dengan latar belakang pendidikan umum juga menunjukan kemampuan yang baik. Kondisi tersebut mengonfirmasi hasil penelitian yang menunjukkan bahwa siswa lulusan Madrasah Ibtidaiyah memiliki kemampuan membaca al-qur'an lebih baik dibanding siswa lulusan Sekolah Dasar (Lamkhatul Khunainah, 2018:99).

Mahasiswa dengan kemampuan membaca al-qur'an yang rendah mengalami kesulitan dalam mengikuti perkuliahan pada mata kuliah ulumul qur'an, Hadits dan mata kuliah lainnya yang tentunya menyentuh kajian keislaman dan literatur dari al-qur'an sebagai sumber utama. Mata kuliah tersebut berkaitan dengan lulusan FTIK IAIN Pontianak yang akan menjadi Guru mata pelajaran fiqh, al-qur'an hadits, aqidah akhlak dan Sejarah Kebudayaan Islam (Saekan Muchith, 2015:220). Semua disiplin keilmuan yang harus dikuasai bersentuhan langsung dengan al-qur'an, hal ini akan menjadi problem tersendiri bagi guru lulusan FTIK jika saat memberikan pembelajaran kurang mampu mengakses dengan baik literatur yang diperlukan. Misalnya, saat mengajar mata pelajaran al-qur'an hadits tentang tata cara melafadzkan hukum bacaan "qolqolah", guru harus mampu mendemonstrasikan hukum bacaan dimaksud di hadapan siswa, maka kemudian kemampuan melafadzkan makhorijul huruf dan tajwid seyogyanya telah dikuasai guru.

Lemahnya kemampuan membaca al-qur'an mengakibatkan mahasiswa mengalami hambatan tidak hanya saat menjadi Guru tetapi sejak dalam proses perkuliahan. Hambatan mengikuti materi perkuliahan tentang kajian keislaman akan berimbas pada lemahnya kompetensi Guru terutama dalam memberikan pembelajaran mata pelajaran al-qur'an dan Hadits. Kompetensi pedagogik harus dimiliki yakni berupa penguasaan terhadap metode dan materi yang hendak diajarkan, disamping itu guru senantiasa mengamalkan materi yang diajarkan (Ramayulis, 2005:51). Beberapa kebijakan kelembagaan telah dilakukan sebagai upaya untuk meningkatkan kemampuan mahasiswa dalam membaca al-qur'an.

Mahasiswa semester 1 (satu) diwajibkan mengikuti praktikum Qira'ah dan ibadah (praktek membaca al-qur'an dan ibadah) selama 1 (satu) semester, ketuntasan mengikuti program tersebut diganjar dengan sertifikat yang kemudian menjadi salah satu syarat mengikuti ujian skripsi di IAIN Pontianak khususnya FTIK. Pembelajaran tambahan berupa praktikum qiraah dan ibadah dilaksanakan sekali dalam sepekan dan diatur Dosen pembimbing pada masing-masing kelas. Program tersebut dirasa belum memberikan dampak sebagaimana diharapkan, nyatanya tidak sedikit mahasiswa yang akan melaksanakan ujian skripsi masih terbata-bata saat diminta membaca al-qur'an meskipun telah mengantongi sertifikat kelulusan program praktikum qira'ah dan ibadah.

Menyikapi problematika dimaksud kemudian IAIN Pontianak menetapkan dan melaksanakan program IAIN Mengaji bagi mahasiswa semester 1 (satu) sampai semester 2 (dua), tujuan utamanya untuk meningkatan kemampuan mahasiswa dalam membaca al-qur'an. Program IAIN Mengaji dimulai pada semester genap

500 BRILIANT: Jurnal Riset dan Konseptual

Volume 5 Nomor 3, Agustus 2020 
tahun akademik 2019-2020 dan akan terus berjalan dibawah pengawasan masingmasing Fakultas di IAIN Pontianak. Program IAIN Pontianak berisi 3 (tiga) program prioritas, yang pertama tahsin alqur'an sebagai program utama, selanjutnya pembinaan akhlak dan pembinaan praktek ibadah. Ketiga program tersebut harus diikuti oleh mahasiswa lulusan IAIN Pontianak, khususnya mahasiswa FTIK sebagai calon Guru.

Khusus program peningkatan kemampuan membaca atau tahsin al-qur'an diterapkan metode pembelajaran tutor sebaya. Metode ini memanfaatkan teman sebaya yang memiliki kemampuan menyerap pembelajaran lebih baik atau telah tuntas mempelajari suatu materi pembelajaran maupun disiplin keilmuan tertentu untuk memberikan bantuan terhadap rekannya yang masih mengalami kesulitan menguasai bahan pembelajaran yang sedang dipelajari (Arjanggi dan Suprihatin, 2010:91-97). Pembelajaran model tutor sebaya dapat membangun suasana belajar kelompok yang kooperatif sehingga pembelajaran berlangsung menyenangkan bagi peserta didik. Menurut Djamarah dan Zain (2015 : 26) manfaat menggunakan metode tutor sebaya yakni (1) mampu mengikis perasaan canggung dan segan terhadap guru saat akan mengungkapkan pendapat dan mengajukan pertayaan; (2) Momentum bagi siswa yang bertindak sebagai tutor untuk melakukan telaah kembali materi dan melatih diri mengemban tanggung jawab serta kesabaran; (3) media mempererat hubungan sosial antar siswa.

Berdasarkan pendapat di atas, pemilihan metode Tutor Sebaya memudahkan mahasiswa dalam melakukan interaksi selama pembelajaran berlangsung, kemudahan tersebut mampu memberikan pengaruh positif terhadap pemahaman siswa dalam menyerap materi pembelajaran. Pemilihan tutor pada program FTIK IAIN Pontianak Mengaji dilaksanakan secara demonstratif dihadapan seluruh mahasiswa, secara bergantian mahasiswa diminta untuk membaca beberapa ayat al-qur'an sehingga menumbuhkan kepercayaan kepada seluruh mahasiswa terhadap tutor yang telah ditunjuk. Menurut Djamarah dan Zain (2015:25) mahasiswa yang ditunjuk sebagai tutor tidak hanya memiliki pengetahuan lebih baik dibanding temannya yang lain, beberapa kriteria sebagai syarat menjadi tutor antara lain: (1) tidak memiliki resistensi, artinya harus dapat diterima oleh mahasiswa lainnya di suatu kelompok; (2) mampu memberikan penjelasan secara mendalam; (3) dapat mengayomi temannya, tidak sombong tetapi tegas; (4) memiliki kreatifitas yang cukup untuk memberikan bimbingan kepada temannya. Program belajar membaca al-Qur'an diampu oleh Dosen yang ditugaskan sebagai fasilitator, kemudian menunjuk tutor berdasarkan uji coba secara demonstratif dihadapan seluruh mahasiswa di suatu kelas, cara tersebut sekaligus upaya untuk meyakinkan mahasiswa lainnya bahwa calon tutor memenuhi kualifikasi yang dibutuhkan.

Uraian di atas kemudian mendasari penelitian ini untuk mempelajari pelaksanaan program FTIK Mengaji yang merupakan agenda akademik bagi peningkatan kompetensi mahasiswa khususnya kemampuan membaca al-qur'an menggunakan metode Tutor Sebaya. Sebagai sebuah program pembelajaran yang baru dilaksanakan dengan ekspektasi tinggi akan keberhasilan program ini, diperlukan sebuah pengamatan secara objektif dan terukur. Penelitian ini bertujuan: 1) mengidentifikasi jenis program FTIK Mengaji bagi mahasiwa tahun akademik 2019/2020; 2) mengamati perencanaan program FTIK Mengaji menggunakan metode tutor sebaya bagi mahasiswa tahun akademik 2019/2020 dan; 3) 
Mendeskripsikan pelaksanaan program FTIK mengaji menggunakan metode tutor sebaya bagi mahasiswa tahun akademik 2019/2020 sebagai rekomendasi kepada pemangku kebijakan untuk menentukan langkah-langkah pengembangan program.

\section{METODE}

Jenis penelitian yang digunakan adalah kualitatif berupa prosedur memahami suatu fenomena alamiah yang dipahami oleh subjek penelitian secara holistik dengan pendekatan deskriptif dan menggunakan berbagai metode ilmiah (Moleong, 2010:6). Peneliti mendeskripsikan pelaksanaan program FTIK Mengaji yang menggunakan metode tutor sebaya dengan mengambil sampel 1 (satu) kelas pada mahasiswa semester 2 (dua) tahun akademik 2019/2020 berjumlah 40 Mahasiswa, pemilihan sampel ini dilakukan karena pelaksanaan program di kelas tersebut peneliti menganggap mampu memberikan data penelitian yang dibutuhkan.

Teknik pengumpulan data berupa observasi partisipasi (Sudaryono, 2018:216), dimana peneliti ikut serta dalam kegiatan FTIK Mengaji dengan bertindak sebagai mentor (dosen pembimbing) mahasiswa. Selanjutnya, penggunaan wawancara tidak terstruktur untuk mendapatkan informasi lebih lengkap terutama saat peneliti menemukan permasalah tertentu selama program berlangsung (Sugiyono, 2016:197). Dokumentasi berupa hasil tes kemampuan awal mahasiswa maupun deskripsi selama berlangsungnya program kegiatan dan untuk menguji kredibilitas data menggunakan triangulasi (Sudaryono, 2018:219).

Teknik analisis data dalam penelitian ini menggunakan model Miles dan Huberman sebagaimana dikutip dalam Sugiyono (2016:305-345) melalui beberapa langkah antara lain: Terlebih dahulu melakukan reduksi data, yakni mengumpulkan dan memilih yang menjadi pokok penelitian serta mengabaikan data-data yang dianggap tidak diperlukan. Kemudian, peneliti melakukan penyajian data dengan menulis uraian singkat terkait temuan selama proses penelitian untuk memberi gambaran yang terjadi. Terakhir, menarik kesimpulan dari seluruh rangkuman temuan selama penelitian dilakukan.

\section{HASIL}

\section{Jenis Program FTIK Mengaji \\ Tahsin Al-Qur'an}

Pelaksanaan program FTIK Mengaji didasari oleh 3 (tiga) hal yang menjadi masalah yang sedang dialami mahasiswa dan perlu diselesaikan antara lain: (1) sebagian besar belum mampu membaca al-qur'an dengan baik; (2) sebagian belum menunjukkan prilaku yang sesuai etika layaknya mahasiswa maupun calon guru; (3) minimnya pemahaman dan keterampilan dalam praktik ibadah. Ketiga masalah ini akan menimbulkan problematika dalam proses pembelajaran, terlebih di kemudian hari setelah menyelesaikan pendidikan di FTIK dan menjadi guru.

Berdasarkan uji kompetensi informal yang dilakukan oleh Dosen saat memberikan perkuliahan, sebagian belum mampu melafadzkan huruf hujaiyah

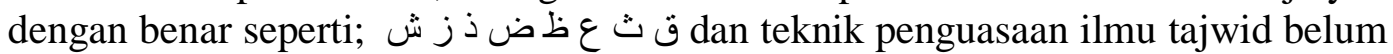
menunjukan kemampuan yang baik. Berdasarkan uji kompetensi salah satu kelas yang berjumlah 40 Mahasiswa didapat hasil antara lain; kemampuan tinggi sebanyak 11 orang, sedang 15 orang dan rendah 14 orang. Penilaian ini mengindikasikan sekitar $70 \%$ mahasiswa di kelas tersebut harus meningkatkan

502 BRILIANT: Jurnal Riset dan Konseptual Volume 5 Nomor 3, Agustus 2020 
kemampuan membaca al-qur'an yang dibutuhkan sebagai pengajar mata pelajaran berbasis nilai-nilai keislaman.

\section{Pembinaan Akhlakul Karimah}

Permasalahan selanjutnya yakni sebagian mahasiswa belum menunjukan sikap dan prilaku selayaknya seorang calon. Sikap dimaksud beberapa diantaranya sebagai berikut;

1) Mengirimkan pesan melalui WA menggunakan redaksi yang kurang sopan. Contohnya: "Assalamu'alaikum. Pak/bu' ada di kampus kah sekarang ? saya mau bertemu", jika dosen menjawab "waalaikumussalam. iya silahkan, saya berada di ruangan". Kemudian, mahasiswa menjawab kembali pesan tersebut dengan jawaban "baik pak, saya masih di kost akan ke kampus sekarang".

2) Berpapasan terhadap dosen belum terbiasa menunjukan sikap hormat layaknya bertemu orang yang lebih tua. Alih-alih mengucapkan salam, beberapa mahasiswa bersikap seolah tidak mengenal Dosen saat bertemu atau berpapasan di lingkungan kampus.

3) Tata cara berpamitan setelah mengakhiri pertemuan dengan Dosen maupun bagian pelayanan akademik yang kurang tepat, sebagian mahasiswa tampak langsung membelakangi lawan bicara saat akan meninggalkan tempat.

\section{Praktik Ibadah}

Praktik ibadah mulai dari tata cara berwudhu, shalat dan pelaksanaan fardhu kifayah (mengurus jenazah) menjadi target selanjutnya dalam program FTIK Mengaji. Masih ditemukan sebagian mahasiswa belum mampu melakukan gerakan wudhu dengan benar, hal ini terlihat saat berwudhu untuk melaksanakan shalat berjemaah di masjid lingkungan kampus IAIN Pontianak. Kemudian, dibekali kemampuan tata cara mengurus jenazah mulai dari memandikan, mengkafani, menyolatkan hingga menguburkan. Disamping hal ini akan menjadi materi ajar saat mengajar siswa, aktivitas mengurus jenazah akan dialami oleh mahasiswa di kehidupan sosialnya.

\section{Perencanaan FTIK Mengaji Dengan Metode Tutor Sebaya \\ Pola Pengawasan}

Program FTIK Mengaji bagi mahasiswa di tahun pertama perkuliahan dilaksanakan setiap hari selama 60 menit pada jadwal aktif perkuliahan. Maka, perkuliahan yang sejatinya dimulai jam 07.00 WIB bergeser menjadi jam 08.00 WIB. Mahasiswa tetap diwajibkan hadir pada jam 07.00 WIB meskipun perkuliahan dilaksanakan pukul 08.00 WIB karena wajib mengikuti kegiatan FTIK Mengaji terlebih dulu, pemantauan kedisiplinan dilakukan melalui lembar absensi khusus program mengaji dibawah bimbingan dan pengawasan dosen yang ditugaskan pada masing-masing kelas maupun dosen pengampu mata kuliah di jam pertama perkuliahan. Dosen pembimbing program FTIK Mengaji dibantuan oleh Ormawa (Organisasi Kemahasiswaan) yang terdiri dari Dewan Mahasiswa, Himpunan Mahasiswa Program studi dan organisasi lainnya dalam melakukan pengawasan terhadap mahasiswa saat berlangsungnya program. Dosen pembimbing melaporkan hasil pengawasannya kepada Dekan FTIK dan secara teknis melalui Wakil Dekan bidang akademik dan pengembangan lembaga.

\section{Kriteria Tutor}


Metode tutor sebaya dilakukan untuk mengatasi keterbatasan jumlah pembimbing yang hanya tersedia 1 (satu) dosen di dalam satu ruang kelas, sedangkan mahasiswa di setiap kelas pada angkatan 2019/2020 rata-rata berjumlah 35-40 orang. Metode tutor sebaya menjadi alternatif dalam menyiasati problem dimaksud agar pelaksanan program tetap berjalan efektif dan mendapatkan hasil yang sesuai harapan. Keputusan menggunakan metode tutor sebaya dilandasi kesadaran bahwa, dalam setiap kelas terdapat mahasiswa yang memiliki kemampuan membaca al-qur'an sangat baik bahkan beberapa mahasiswa secara aktif mewakili daerah asalnya mengikuti even perlombaan seni membaca al-qur'an seperti Musabaqah Tilawatil Qur'an (MTQ) maupun agenda sejenis dari tingkat kecamatan hingga tingkat Nasional. Disamping itu, mahasiswa lulusan Pondok Pesantren relatif memiliki kemampuan sangat baik, tidak mungkin diabaikan potensinya untuk menjadi tutor bagi teman-temannya di kelas yang masih memiliki kemampuan sedang maupun rendah.

\section{Pembinaan Kemampuan Makharijul Huruf dan Tajwid}

Pembagian klasifikasi skala kemampuan mahasiswa membaca al-qur'an ke dalam indikator tinggi (mahir), sedang dan rendah sebagai pedoman penilaian bagi dosen pembimbing secara kualitatif sebagai berikut : (1) Tinggi, mahasiswa mampu melafadzkan hukum bacaan dan membedakan huruf hijaiyah yang hampir sama dengan baik dan benar; (2) Sedang, mahasiswa kurang mampu melafadzkan hukum bacaan dan membedakan huruf hijaiyah yang hampir sama dengan baik dan benar; (3) Rendah, mahasiswa tidak mampu melafadzkan hukum bacaan dan membedakan huruf hijaiyah yang hampir sama dengan baik dan benar.

Program FTIK Mengaji diisi pula dengan pembelajaran akhlak, bentuk kegiatan akhlak bersifat praktik, materi yang disampaikan menyasar prilaku mahasiswa di kampus terutama terkait prilaku sebagai seorang Guru. Prilaku sebagian mahasiswa dianggap belum mencerminkan sikap selayaknya yang harus ditampilkan, prilaku dimaksud antara lain; sikap mahasiswa saat mengirimkan pesan singkat melalui WA masih ditemukan redaksi yang diaggap kurang baik, sikap kurang elegan ditunjukkan saat bertemu di jalan atau berpapasan di lingkungan kampus dan beberapa prilaku lainnya yang harus dilatih agar sesuai dengan norma dan etika Keguruan. Selanjutnya, praktik ibadah tak lepas dari perhatian dan perlu ditingkatkan, sebagai calon guru dengan basis keahlian tentang ajaran agama Islam harus memiliki kompetensi yang mumpuni terutama pelaksanaan wudhu, shalat, pengurusan jenazah dan lain-lain. Pembinaan akhlak dan praktik ibadah dilaksanakan masing-masing 1 (satu) hari dalam seminggu (5 hari kerja) berdasarkan kalender akademik, sehingga 2 (dua) hari khusus untuk pembinaan akhlak dan praktik Ibadah dan 3 (tiga) hari dimanfaatkan untuk peningkatan kemampuan (tahsin) Al-qur' an sebagai program utama.

\section{Pelaksanaan Program FTIK Mengaji Menggunakan Metode Tutor Sebaya Tata Tertib}

Adapun tata tertib yang harus dipatuhi oleh mahasiswa peserta FTIK Mengaji antara lain; (1) Mahasiswa wajib masuk kelas mulai jam 07.00-08.00 WIB, (2) Bebusana yang sopan dan layak, (3) membawa kitab suci al-qur'an, (4) belajar dengan sungguh-sungguh, (5) menjaga kebersihan, kerapian, dan kenyamanan ruang kelas, (6) mahasiswa wajib mengisi absensi kehadiran; dan (7) mahasiswa

504 BRILIANT: Jurnal Riset dan Konseptual

Volume 5 Nomor 3, Agustus 2020 
yang tidak hadir tanpa keterangan lebih dari 3 kali akan diberikan sanksi. Sanksi dimaksud bisa berupa tidak dikeluarkannya surat keterangan telah mengikuti program FTIK Mengaji, yang berarti konsekuensinya tidak dapat mengikuti ujian skripsi karena surat keterangan dimaksud sebagai salah satu syarat tidak terpenuhi.

\section{Indikator Penilaian}

Program pembelajaran membaca al-qur'an menggunakan metode tutor sebaya diterapkan sebagai upaya meningkatkan kemampuan mahasiswa. Hampir seluruh mahasiswa FTIK telah memiliki kemampuan dasar membaca al-qur'an meskipun di setiap kelas didominasi oleh mahasiswa dengan kemampuan sedang dan rendah. Mahasiswa mengikuti program menggunakan tutor sebaya dengan baik, dosen pembimbing membentuk mahasiswa menjadi beberapa kelompok, setiap kelompok berjumlah 3-4 orang dan diketuai oleh satu orang mahasiswa dengan kemampuan tinggi sekaligus sebagai tutor.

Penelitian ini telah mengambil sampel salah satu kelas pada mahasiswa Program Studi Pendidikan Agama Islam (PAI) semester 2 (dua) Tahun akademik 2019/2020, didapatkan hasil antara lain: Tinggi, berjumlah 11 orang; Sedang, berjumlah 15 orang dan; Rendah, berjumlah 14 orang.

Anggota kelompok dibagi secara proporsional terdiri dari mahasiswa dengan kemampuan sedang dan rendah. Mahasiswa berkumpul dengan membentuk lingkaran kecil pada masing-masing kelompok, pembelajaran diawali dengan membaca surah al-fatihah bersama-bersama, kemudian mahasiswa yang ditunjuk sebagai tutor pada masing-masing kelompok membimbing temannya secara bergiliran. Selama pelaksanaan program mengaji, dosen pembimbing berkeliling mengamati proses pembelajaran yang dilakukan oleh mahasiswa dan sesekali ikut memberikan saran terkait hal-hal yang dirasa kurang tepat, disamping itu dosen pembimbing juga melakukan bimbingan langsung kepada mahasiswa sekaligus memanfaatkannya untuk mengamati perkembangan kemampuan mahasiswa.

\section{Metode Pembelajaran}

Seluruh mahasiswa FTIK IAIN Pontianak telah memiliki dasar membaca al-qur'an, bahkan mahasiswa dengan kemampuan paling rendah sekalipun telah mengenal huruf hijaiyah tetapi harus ditingkatkan. Bimbingan yang dilakukan oleh tutor pada masing-masing kelompok yang sebelumnya telah ditentukan oleh dosen pembimbing selaku mentor terdiri dari 3-4 orang, mahasiswa duduk bersama di bawah bimbingan 1 (satu) orang tutor, setiap kelompok diberi kesempatan untuk meminta penjelasan dari dosem pembimbing terkait hal-hal yang belum dipahami terutama terkait sistem pembelajaran (Hamalik, 2017:163). Sebelum proses pembelajaran kelompok dimulai, dosen pembimbing memberikan pengantar berupa materi maupun petunjuk pembelajaran yang harus dikuasai, khususnya terkait makharijul (tempat keluar) huruf dan pengetahuan tentang dasar-dasar hukum bacaan (tajwid) dalam membaca al-qur'an.

\section{Efektivitas dan Hambatan}

Program pembelajaran membaca al-qur'an menggunakan metode tutor sebaya berjalan dengan baik, mahasiswa bersedia mengikutinya secara terbimbing meskipun yang menjadi pembimbing adalah teman sebayanya. Kesadaran 
mengikuti program FTIK IAIN Pontianak Mengaji khususnya belajar membaca alqur'an terbilang baik dan berlangsung sesuai harapan.

Permasalahan paling menyita perhatian yakni terkait disiplin kehadiran sebagian kecil mahasiswa, seharusnya mahasiswa harus hadir sebelum atau tepat jam 07.00 WIB untuk mengikuti program tahsin al-qur'an. Beberapa mahasiswa bahkan orang yang sama hampir setiap hari hadir di kelas tidak tepat waktu, dengan mengungkapkan berbagai alasan seperti; jarak tempat tinggal yang terlampau jauh, bangun tidur kesiangan, menunggu saudara karena tidak memiliki kendaraan sendiri maka terpaksa menumpang dan beberapa alasan lainnya.

\section{PEMBAHASAN}

Lulusan FTIK IAIN Pontianak harus menguasai kemampuan membaca alqurán, akhlakul karimah dan praktik ibadah, disamping pengetahuan dan keterampilan lain dalam menjalankan profesi Keguruan. Kemampuan membaca alqur'an sebagai modal dasar guru lulusan FTIK IAIN Pontianak yang bersentuhan langsung dengan sumber-sumber al-qur'an dan Hadits, sejak masa perkuliahan seluruh mahasiswa perlu menguasai teknik membaca al-qur'an. Kemampuan membaca al-qur'an bagian dari kompetensi profesional yakni penguasaan materi, konsep, pola pikir keilmuan yang mendukung mata pelajaran yang diampu dan mengembangkannya secara reflektif (Irwanto dan Yusuf Suryana, 2016:4).

Sulit membayangkan jika menjadi Guru lulusan Perguruan Tinggi dengan basis kajian keislaman kurang cakap membaca al-qur'an yang menjadi kompetensi paling mendasar untuk melakukan telaah mendalam terkait sumber utama pembelajaran. Mahasiswa FTIK IAIN Pontianak sebagian besar memiliki kemampuan membaca al-qur'an dalam kategori sedang dan rendah, sebagian lagi berada pada kategori tinggi atau mahir.

Fokus utama dari program FTIK Mengaji yakni meningkatkan kemampuan membaca al-Qurán bagi mahasiswa, disamping itu program peningkatan akhlakul karimah tak luput dari perhatian. Menurut Ulva Rahmi dkk (2018:70-78) sebuah pesan (SMS/WA) dianggap tidak sopan dan tidak mengikuti etika, jika tidak mencantumkan identitas yang jelas, keperluan dan mengabaikan kondisi dosen yang bersangkutan saat itu. Gambaran pola komunikasi melalui pesan singkat sebagaimana dimaksud ditunjukkan oleh beberapa mahasiswa FTIK IAIN Pontianak. Bahkan dalam beberapa kasus, mahasiswa mengirimkan pesan singkat dalam rangka meminta waktu bertemu, setelah dosen yang bersangkutan menyanggupi keinginan mahasiswa dan meminta segera mendatangi ruangan dosen, mahasiswa tersebut malah memberikan jawaban bahwa masih berada di kediamannya. Hal ini mengesankan bahwa mahasiswa mengabaikan tata cara berkomunikasi yang layak terhadap Dosen, karena dapat dimaknai sebagai tindakan membohongi dosen yang bersangkutan, dalam pesan pembuka dari mahasiswa seolah-olah mahasiswa sedang berada di kampus dan telah mempersiapkan diri menemui dosen saat itu pula, yang terjadi justeru sebaliknya. Meskipun, Dosen maupun Mahasiswa harus berada di lingkungan kampus dan Dosen tetap harus bersedia memberikan layanan terhadap mahasiswa selama jam kerja, namun model komunikasi di atas tidak dibenarkan karena mengindikasikan upaya mengelabui pihak yang akan ditemui.

Sopan santun diperlukan dalam bersikap dan berbicara, berpakaian sopan, dan membudayakan senyum, salam, sapa khususnya saat bertemu di jalan (Hidayat,

506 BRILIANT: Jurnal Riset dan Konseptual

Volume 5 Nomor 3, Agustus 2020 
2013:1-12). Seyogyanya, ketika seorang mahasiswa selesai berurusan dengan Dosen atau petugas administrasi, mahasiswa sebaiknya melakukan gerakan mundur beberapa langkah terlebih dahulu sehingga jarak antara keduanya relatif jauh, kemudian dapat melakukan gerakan memutar dan berjalan secara normal. Disamping itu, tidak sedikit mahasiswa yang sering mengeluarkan komentar secara spontan saat Dosen sedang menjelaskan, padahal belum diberi kesempatan untuk mengungkapkan pendapatnya. Menurut Al-Zarnuji dalam Abdul Kadir (2012:103) sikap ta'zim (amat hormat dan sopan) kepada guru atau dosen salah satunya tidak memulai berbicara tanpa izin dari Guru.

Program FTIK Mengaji selanjutnya yakni pembinaan praktik Ibadah. Menurut Arifah dalam Sovia (2017:20) Praktik ibadah adalah proses belajar yang mengarahkan mahasiswa mengenal, memahami, menghayati dan mengamalkan syariat Islam melalui bimbingan, pelatihan dan pengamalan dalam kehidupan sehari-hari sebagaimana telah diterapkan terhadap mahasiswa di Ma'had Al-Jamiah UIN Raden Intan lampung. Gerakan wudhu yang ditunjukan relatif kurang baik bahkan terkesan mengabaikan kesempurnaan wudhu. Menjaga kesucian pakaian yang akan digunakan untuk melakukan ibadah khususnya shalat belum mendapat perhatian mahasiswa IAIN Pontianak, sebagian mahasiswa melaksanakan shalat menggunakan pakaian maupun celana panjang yang sebelumnya telah digunakan untuk duduk di lantai depan kelas maupun bagian-bagian lain di lingkungan kampus yang rentan terkena najis.

Pelaksanaan FTIK IAIN Mengaji diawali dengan membaca al-qur'an bersama-sama, pembimbing juga ikut membaca al-qur'an sembari mengamati dan memastikan mahasiswa mengikuti aktivitas tersebut dengan baik. Sebagaimana tujuan utama program FTIK Mengaji adalah meningkatkan kemampuan mahasiswa dalam membaca al-qur'an. Pembimbing meminta setiap Mahasiswa secara bergiliran membaca beberapa ayat al-qur'an, hal ini dilakukan untuk memberikan penilaian terhadap kemampuan masing-masing mahasiswa. Mendengarkan bacaan al-qur'an yang didemonstrasikan bertujuan untuk membagi kemampuan mahasiswa ke dalam 3 (tiga) kategori yakni tinggi (mahir), sedang dan rendah (Mustafidah, 2016:41-43). Klasifikasi kemampuan membaca al-qur'an menjadi dasar bagi pembimbing dalam menentukan bentuk bimbingan yang akan diterapkan. Mahasiswa dengan kemampuan tinggi (mahir) akan ditugaskan sebagai tutor atau pengajar bagi rekannya yang masih dalam kategori sedang dan rendah, sedangkan mahasiswa dengan kemampuan sedang dan rendah akan mengikuti bimbingan dari rekannya yang telah memiliki kemampuan tinggi (Astuti dan Heliati, 2017:212228).

Indikator kemampuan membaca al-qur'an akan diungkapkan 2 (dua) diantaranya: (1) ketepatan melafadzkan Makharijul huruf, kesempurnaan dalam membunyikan huruf hijaiyah sesuai dengan tempatnya (Safarina, 2015:113-144); (2) Ketepatan tajwid, yang berarti membaguskan bacaan dengan menempatkan huruf dan bacaan al-qurán berdasarkan hak maupun mustahakhahnya (Aso sudiarjo, 2015:54-60). Program FTIK Mengaji fokus terhadap peningkatan kemampuan melafadzkan makharijul huruf (tempat keluar huruf) dan tajwid sebagai pondasi awal mengasah kemampuan tartil dan lainnya. Khusus mahasiswa dengan kemampuan rendah, sejatinya secara umum telah mampu membaca alqur'an tetapi masih perlu ditingkatkan lagi kemampuan melafadzkan makharijul 
(tempat keluar) huruf maupun dalam mempraktekkan tajwid (hukum bacaan) yang belum sempurna.

Klasifikasi kemampuan membaca al-qur'an menggunakan rating scale (skala rating) yakni data mentah berupa angka dalam penelitian ditransformasikan menjadi data kualitatif (Sugiyono, 2016:141). Instrumen tes kemampuan awal mahasiswa terdiri dari 2 (dua) indikator utama antara lain; 1) makharijul huruf: kemampuan melafadzkan huruf hijaiyah dan kemampuan membedakan huruf hijaiyah yang lafadznya hampir mirip. 2) Tajwid: kemampuan melafadzkan mad, qolqolah, idghom, ikhfa' dan iklab. Kemampuan mahasiswa dinggap Tinggi jika mampu melafadzkan maupun membedakan dengan baik dan benar. Kemampuan sedang jika kurang mampu melafadzkan maupun membedakan dengan baik dan benar. Sedangkan, kemampuan rendah jika tidak mampu melafadzkan dan membedakan dengan baik dan benar. Penilaian tersebut diserahkan sepenuhnya kepada mentor atau dosen pembimbing yang kemampuannya dianggap layak untuk memberikan penilaian kemampuan mengaji terhadap mahasiswa.

Pembelajaran membaca al-qur'an oleh tutor dilakukan melalui tahsin dengan pendekatan individual, setiap anggota kelompok dibimbing satu per satu sehingga menguasai bacaan dimaksud dengan baik dan benar (Munir, 1994:23). Pembelajaran membaca al-qur'an oleh tutor dilakukan melalui tahsin dengan pendekatan individual, setiap anggota kelompok dibimbing satu per satu sehingga menguasai bacaan dimaksud dengan baik dan benar (Munir, 1994:23). Bacaan yang dianggap kurang tepat, seketika itu pula dilakukan koreksi dan memberikan contoh lafadz (tata cara membaca) yang benar, cara tersebut dilakukan secara berulangulang hingga dirasa menunjukan perubahan yang lebih baik. Dosen pembimbing menekankan kepada tutor agar memfokuskan pembelajaran pada kualitas bacaan, harus melakukan bimbingan hingga layak dianggap baik meskipun dalam setiap pertemuan hanya mampu menyelesaikan satu ayat atau satu baris dari bagian mushaf al-qur'an.

Program FTIK Mengaji diharapkan dapat melatih kedisiplinan mahasiswa, kedisiplinan menjadi salah satu faktor penentu keberhasilan program ini. Menyadari hal tersebut, program FTIK mengaji menerapkan tata tertib yang pengawasannya dilakukan oleh Dosen pembimbing dan wakil dekan bidang akademik dan pengembangan lembaga. Wakil Dekan bidang akademik dan pengembangan lembaga melakukan pemantauan setiap pagi dengan menyusuri seluruh kelas yang menjadi subjek program untuk memastikan pelaksanannya berlangsung dengan baik, Dosen pembimbing menegakan dan melakukan pegawasan terhadap penerapan tata tertib yang telah ditetapkan.

Peneliti awalnya menduga bahwa kesediaan mahasiswa belajar kepada teman sebaya karena di bawah pengawasan Dosen pembimbing, maka pembimbing memastikan asumsi tersebut dengan cara meninggalkan ruang kelas dalam jangka waktu tertentu, kemudian secara diam-diam mengamati aktivitas mahasiswa dari celah pintu, nyatanya mahasiswa masih dalam keadaan relatif tertib meskipun tidak sama saat kehadiran dosen pembimbing di kelas. Di luar pengawasan dosen pembimbing, mahasiswa mengikuti bimbingan dari tutor selama pelaksanaan mengaji berlangsung, meskipun terdapat sebagian kecil mahasiswa terlihat beranjak dari tempat duduknya untuk berkunjung kepada kelompok lain dan beberapa mahasiswa terlihat mengabaikan mushaf al-qur'an dihadapannya.

508 BRILIANT: Jurnal Riset dan Konseptual

Volume 5 Nomor 3, Agustus 2020 
Keterlambatan rata-rata mulai dari 15-40 menit bahkan suatu ketika ditemukan mahasiswa hadir melewati jam 08.00 WIB stelah berakhirnya program. mengacu kepada kebijakan yang telah diketahui dan disepakati oleh seluruh Mahasiswa peserta program, bahwa toleransi keterlambatan yakni maksimal 15 menit dan jika melewati batas tersebut dianggap tidak mengikuti program di hari tersebut, secara akumulasi dalam satu semester harus hadir paling sedikit sebanyak $75 \%$. Konsekuensi dari kelalaian tersebut, tidak diberikannya surat keterangan lulus program FTIK Mengaji yang akan berimbas pada terhambatnya pelaksanaan ujian skripsi di kemudian hari. Surat keterangan lulus merupakan salah satu tujuan semata, yang paling penting adalah bagi mahasiswa dengan kemampuan rendah dan kemudian kurang disiplin dalam mengikuti kegiatan tersebut, dikhawatirkan menghambat peningkatan kemampuan membaca al-qur'an yang bersangkutan.

\section{KESIMPULAN}

Jenis program yang dilaksanakan dalam FTIK Mengaji terdiri dari 3 (tiga) fokus pembinaan yakni tahsin al-Qur'an, pembinaan akhlakul karimah dan praktik ibadah. Program direncanakan dengan menetapkan pola pengawasan program melalui penyediaan absensi kehadiran dan melibatkan organisasi kemahasiswaan maupun dosen pembimbing selaku mentor yang kemudian menyampaikan laporan kepada Dekan melalui Wakil Dekan Bidang Akademik dan Pengembangan Lembaga, menentukan kriteria tutor dan memfokuaskan kepada peningkatan kemampuan melafadzkan makharijul huruf dan Tajwid. Dalam pelaksanaannya, Program FTIK Mengaji menerapkan peraturan yang wajib dipatuhi mahasiswa, tugas mentor adalah mengklasifikasi kemampuan mahasiswa terdiri dari tinggi; sedang dan rendah untuk kemudian menentukan seorang tutor maupun anggota yang dibina, kemudian metode yang diterapkan berupa bimbingan satu per satu dihadapan tutor, tutor berasal dari mahasiswa dengan kemampuan tinggi dan program terlaksana dengan baik meskipun masih memiliki hambatan yakni beberapa mahasiswa tidak hadir tepat waktu.

\section{SARAN}

Program FTIK Mengaji menggunakan metode Tutor Sebaya dapat dipertahankan karena memberikan manfaat signifikan dalam upaya meningkatkan kemampuan membaca al-qur'an Mahasiswa. Sebaiknya, mahasiswa yang ditunjuk sebagai tutor dibekali dengan instrumen sebagai panduan untuk melakukan pengamatan terhadap perkembangan kemampuan anggota kelompok yang diberi bimbingan. Instrumen tersebut menjadi dasar pertimbangan bagi para dosen pembimbing maupun penanggung jawab program dalam mengamati perkembangan kemampuan mahasiswa, dan sebagai dasar pertimbangan memberikan perlakuan terhadap mahasiswa yang perkembangan kemampuan membaca al-quránnya relatif lambat.

\section{DAFTAR RUJUKAN}

Al-Zarnuji, Syaikh. 2012. Ta'lim Muta'allim terjemahan Abdul Kadir al-Zufri. Surabaya: Mutiara Ilmu.

Arjanggi. R, Suprihatin. T. 2010. Metode Pembelajaran Tutor Teman Sebaya Meningkatkan Hasil Belajar Berdasar Regulasi Diri. Makara Seri Sosial Humaniora. 14(2), 91-97. DOI:10.7454/mssh.v14i2.666 
Ariani, Safrina dan Realita. 2015. Program Bengkel Mengaji (Upaya Peningkatan Kemampuan Tahsin Qur'an Mahasiswa PAI). Jurnal Mudarrisuna. 5(1), 113-144

Astuti, Sri dan Heliati Fajriah. 2017. Peningkatan Kemampuan Tahsin Al-Qur'an Pada Mahasiswa PAI UIN Ar-Raniry: Efektivitas Metode Pee Tutoring Melalui Program Bengkel Mengaji. Al-Ishlah. 15(2), 212-228.

Djamarah dan Zaini. 2015. Strategi Belajar Mengajar. Jakarta: Rineka Cipta Hidayat, Ade. 2013. Persepsi dan Prilaku Mahasiswa Dalam Pendidikan Karakter (Studi Deskripsi di Fakultas Keguruan dan Ilmu Pendidikan Universitas Mathla'ul Anwar Banten Tahun 2013). Jurnal Etika dan Pekerti. 1(2), 112.

Hamalik, Oemar. 2017. Proses Belajar Mengajar. Jakarta: Bumi Aksara

Irwanto, Nur dan Yusuf Suryana (2016). Kompetensi Pedagogik; Untuk Peningkatan dan Penilaian Kinerja Guru Dalam Rangka Implementasi Kurikulum Nasional. Surabaya: Genta Group

Khunainah, Lamkhatul. 2018. Studi Komparasi Kemampuan Membaca Al-Qur'an Antara Lulusan MI dan SD Pada Kelas VII di MTsN 2 Kendal. Skripsi. 1145.

Masrur, Imam. 2018. Telaah Kritis Syarat Mufassir Abad Ke-21. Jurnal QOF: Studi Al-Qur'an dan Tafsir. 2 (2), 187-201. https://doi.org/10.30762/qof.v2i2.557.

Mas Ayu, Sovia. 2017. Evaliasi Prgram Praktek Pengalaman Ibadah di Sekolah Dasar Ar-Raudah Bandar Lampung. Al-Tadzkiyyah: Jurnal Pendidikan Islam. 8(1), 15-29

Moleong, Lexy. J. 2010. Metodologi Penelitian Kualitatif. Bandung: Rosdakarya

Muchith, Saekan M. 2016. Guru PAI Yang Profesional. Quality : Journal of Empirical Research In Islamic Education. 4(2). 218-235. http://dx.doi.org/10.21043/quality.v4i2.2121.

Munir, Ahmad dan Soedarso. 1994. Imu Tajwid Seni Baca Al-Qur'an. Jakarta: Bineka Cipta

Mustafidah, Imrotul. 2016. Korelasi Antara Kemampuan Membaca Al-Qur'an Dengan Hasil Belajar Mata Pelajaran Al-Qur'an Hadits Siswa Kelas V MI NU 65 Gebanganom Kecamatan Rowosari Kabupaten Kendal Tahun Ajaran 2015/2016. UIN Walisongo Semarang.

Rahmi, Ulva dkk. 2018. Kesantunan Bahasa SMS (Short Message Service) Mahasiswa Terhadap Dosen Bahasa Indonesia Pada Semester Ganjil 2017/2018 Di Universitas Mahaputra Muhammad Yamin Solok. Jurnal Pendidikan Bahasa dan Sastra. 1(7) 70-78

Ramayulis. 2005. Metodologi Pendidikan Agama Islam. Jakarta: Kalam Mulia Sudaryono. 2018. Metodologi Penelitian. Depok: Rajawali Pers

Sudiarjo, Aso dkk (2015). Aplikasi Pembelajaran Ilmu Tajwid, Waqaf dan Makharijul Huruf Berbasis Android. Jurnal Sisfotek Global. 5(2), 54-60

Sugiyono. 2016. Metode Penelitian Pendidikan; Pendekatan Kuantitatif, Kualitatif dan $R \& D$. Bandung: Alfabeta 